\title{
Women in Science and Technology: A study in Bangladesh
}

\author{
Hasibun Naher ${ }^{1, *}$, Tasfia Tanim ${ }^{2}$, Nadira Sultana ${ }^{3}$ \\ ${ }^{1}$ Department of Mathematics and Natural Sciences, BRAC University, Bangladesh \\ ${ }^{2}$ Department of English, East West University, Bangladesh \\ ${ }^{3}$ HURDCO International School, Bangladesh
}

Copyright $(2019$ by authors, all rights reserved. Authors agree that this article remains permanently open access under the terms of the Creative Commons Attribution License 4.0 International License

\begin{abstract}
Science and technology are very closely connected in every sphere of our lives. As scientific study aims at conquering knowledge of the complexities in nature and finding solutions to unsolved problems, it is vital for the development of mankind. The constructive influences of technology are numerous. The human life has been modernized for the development in this field. Science and Technology serves as the engine of development of a country and an engine of change for the society. An inclusive gender gap has continued over the years at all fields of STEM disciplines all over the world. Even though the involvement of women in higher education has increased, they are still under-represented. A lack of female representation negatively impacts our future for the society. There is a direct correlation between development of a country and its practice of science and technology. For this purpose, women along with men should be given ample opportunities to enter into and excel in science, technology, and related professions. Women are enterprising in science and technology with the inspiration and knowledge enabling them to utilize their full potential. They are committed to developing themselves as leaders through education, mentorship, networking, and information sharing. The research work is based on data for students, teachers and scientists who are in public, private universities and scientific institutions of Bangladesh. We displayed and illustrated collected data in various tables and also compared male, female students, teachers and scientists and findings disclose that women in all mentioned sectors slightly increased. As half of the total population is women, the main objective of this paper is to highlight the increased involvement of women in STEM field that would allow the country to develop and improve socio-economic prospects.
\end{abstract}

Keywords Female, Science, Technology, Developing Country, Bangladesh

\section{Background}

In the last two decades, remarkable progress has been made but there is also much that remains to be accomplished [1, 2]. Even today in the modern developed world parents still prefer to have a boy rather than a girl. One longstanding reason why boys have been seen as a greater blessing that they are expected to become better economic providers during their parents' old age. Yet it is time for parents to think that girls may now be a better investment. Girls get better grades at school than boys. More women go to university than men. Women will thus be better equipped for the new jobs of the 21st century.

Education is a human right and an essential tool for achieving equality, development, and peace. Female education contributes to poverty alleviation, improved nutrition and reduced fertility [3-6]. Education also improves women's own health outcomes and life expectancy, their ability to influence family decisions and their likelihood of engaging in formal paid employment. Aside from the intrinsic value of education, better-educated women are more productive and have higher incomes; they marry later and may have healthier and better-educated children [5-7]. Perhaps most importantly an educated woman can more easily avoid the vicious cycle of poverty. So many experts are convinced that investment in the education of girls may well be the highest-return investment available in the developing world [6, 7]. Bangladesh is a developing country and behind her less and slow development lack of proper female education is one of the main reasons. Most of the women drop out from pursuing higher education after or before completing secondary level. There are several causes such as poverty, early marriage, lack of parent's education, insufficient stipend, burden of household chores, lack of security and many others. A productive as well as a quality life for all irrespective of whether it is a developed or developing country is a rightful demand of this science and ICT century [7-9]. For this purpose, women-along with 
men - should be given ample opportunities to enter in science, technology, and related professions. Realizing that low representation of women in science and engineering is a major hindrance to global capacity building in science and technology. Women's participation in science and technology professions must be encouraged to strengthen their roles in the development of the country free from hunger, malnutrition and unhealthy environment [1-12]. People will share and use resources in a sustainable way through proper education without gender discrimination. Women's participation must be encouraged both as educators and researchers for addressing different issues.

This work emphasizes on the noteworthiness of education policy which assigns the highest priority to stimulating science, technology, engineering and mathematics (STEM).

\section{The Role of STEM in Development}

Encouraging women to take part in activities involving science and technology would allow the country to develop and maximize its valuable human assets, empowering of women, and improving its economic prospects. Women are enterprising in science and technology with the inspiration and knowledge enabling them to utilize their full potential. They are committed to developing themselves as leaders through education, mentorship, networking, and information sharing. Indicators and information are required for females in many countries to help understand and address this situation of declining interest in and entry into science and engineering, and the consequences there of for capacity and application of science, engineering and technology (SET) for social and economic development. We need data and information for evidence-based analysis and understanding of the situation, and for policy-making and planning to address the problem in Bangladesh. The situation is complex in developing countries due to shortage of statistical data and proper guidelines on science and engineering.

There are many challenges for women right from the beginning of education to the career development level at home and at working place. It needs rigorous efforts on the part of all to break all biases and prejudices about women scientists, ensure that young girls have the freedom and confidence to pursue careers in science and technology, support students through every academic stage, encourage women at home and at working place, create an environment to attract women to professional lives, balancing family life, ensuring their security and help them in confidence building. The government should take specific steps to provide special incentives to women engaged in research and development (R\&D) activities.
This has been addressed in the National Science and Technology Policy 2011 ensuring women's participation as well as empowering them in every sphere of science and technology related education and research. Efforts should be made for international research collaboration, networking and the ability to disseminate scientific knowledge among fellow women scientists and exchange of opinions among young female scientists and engineers in Bangladesh in order to develop their leadership skills. The government and the Bangladesh Academy of Science should come forward to initiate this kind of collaboration. Family support, institutional support and most importantly government support are very important for women to succeed in their professional career.

\section{Materials and Methods}

Bangladesh is a developing country. Socio-economic condition is not satisfactory since half of the total population is women. Here men and women do not participate equally in social development. But in market economy women of Bangladesh are always facing new challenges. Though women work in educational institutions, medical professions, factories, police, even in the uneven areas, women are neglected. In the society of gender disparity, it is difficult for women to stay parallel and enjoy the right of equal participant. The development of a country is a continuous process and there is no easy formula for a magic transition. Men and women must work hand in hand and must work hard. The state of science education in schools and colleges in Bangladesh is far from satisfactory. The status of women in science education in the country at different levels for the last couple of years is presented. At each stage of the academic ladder, from high school to highest academic positions, the representation of women in science declines substantially. As they move from high school to college, more women than men who have expressed an interest in science or engineering decide to major in something else; in the transition to graduate school, more women than men with science and engineering degrees opt into other fields of study.

At the present, in Bangladesh, there are 43 public and 97 private universities as per report, April 2018. But in 2017, the number of public and private universities was 40 and 95 respectively, and following tables illustrated number of both universities as per years. The private universities offer mostly BBA, English, Economics, Social Sciences, CSE, EEE, etc. and major in basic science subjects are few and far between. In public universities, seats are limited and for enrolment, the competition is open to both the sexes. It is shown in Table 1 that only $32.57 \%$ of students were females among all public and private universities in 2017. 
Table 1. Number of students in universities by gender of Bangladesh in 2017

\begin{tabular}{|c|c|c|c|c|c|}
\hline University Type & No. of University & Male (Total) & Female (Total) & Female (\%) & Total \\
\hline Public & 40 & 332,881 & 186,607 & 35.92 & 519,488 \\
\hline Private & 95 & 244,789 & 924,49 & 27.41 & 337,238 \\
\hline Total & 135 & 577,670 & 279,056 & 32.57 & 856,726 \\
\hline
\end{tabular}

Source: Bangladesh Education of Statistics 2017

In Table 2, we see that only $35.27 \%$ of students in all public universities and $26.76 \%$ in private universities were women in 2016.

Table 2. Number of students in universities by gender of Bangladesh in 2016

\begin{tabular}{|c|c|c|c|c|c|}
\hline University Type & No. of University & Male (Total) & Female (Total) & Female (\%) & Total \\
\hline Public & 38 & 292,720 & 159,472 & 35.27 & 452,192 \\
\hline Private & 92 & 271,652 & 99,258 & 26.76 & 370,910 \\
\hline Total & 130 & 564,372 & 258,730 & 31.43 & 823,102 \\
\hline
\end{tabular}

Source: Bangladesh Education of Statistics 2016

The percentage of female students was $36.80 \%$ and $27.72 \%$ in all public and private universities respectively in 2015 that are displayed in Table 3.

Table 3. Number of students in universities by gender of Bangladesh in 2015

\begin{tabular}{|c|c|c|c|c|c|}
\hline University Type & No. of University & Male (Total) & Female (Total) & Female (\%) & Total \\
\hline Public & 37 & 311,660 & 181,450 & 36.80 & 493,110 \\
\hline Private & 85 & 274,506 & 105,275 & 27.72 & 379,781 \\
\hline Total & 122 & 586,166 & 286,725 & 32.85 & 872,891 \\
\hline
\end{tabular}

Source: Bangladesh Education of Statistics 2015

Table 4 disclosed the percentage of female students in public and private universities in 2014 which were $37.07 \%$ and $26.71 \%$ respectively.

Table 4. Number of students in universities by gender of Bangladesh in 2014

\begin{tabular}{|c|c|c|c|c|c|}
\hline University Type & No. of University & Male (Total) & Female (Total) & Female (\%) & Total \\
\hline Public & 34 & 286,031 & 168,499 & 37.07 & 454,530 \\
\hline Private & 78 & 292,553 & 106,629 & 26.71 & 399,182 \\
\hline Total & 112 & 578,584 & 275,128 & 30.23 & 853,712 \\
\hline
\end{tabular}

Source: Bangladesh Education of Statistics 2014

It is found that $36.45 \%$ and $28.08 \%$ women were in two types of universities in 2013 that is in Table 5. Moreover, Table 6 illustrated the female students of public and private universities in 2012 such as $34.26 \%$ and $25.27 \%$ respectively.

Table 5. Number of students in universities by gender of Bangladesh in 2013

\begin{tabular}{|c|c|c|c|c|c|}
\hline University Type & No. of University & Male (Total) & Female (Total) & Female (\%) & Total \\
\hline Public & 34 & 279,334 & 160,215 & 36.45 & 439,549 \\
\hline Private & 77 & 267,984 & 104,669 & 28.08 & 372,653 \\
\hline Total & 111 & 547,318 & 264,884 & 32.61 & 812,202 \\
\hline
\end{tabular}

Source: Bangladesh Education of Statistics 2013

Table 6. Number of students in universities by gender of Bangladesh in 2012

\begin{tabular}{|c|c|c|c|c|c|}
\hline University Type & No. of University & Male (Total) & Female (Total) & Female (\%) & Total \\
\hline Public & 34 & 207,954 & 108,377 & 34.26 & 316,331 \\
\hline Private & 52 & 209,845 & 70,977 & 25.27 & 280,822 \\
\hline Total & 86 & 417,799 & 179,354 & 30.03 & 597,153 \\
\hline
\end{tabular}

Source: Bangladesh Education of Statistics 2012 
In Table 7, we see that only $11.6 \%$ of teachers in public universities and $14.40 \%$ in private Universities were women in 2013. In spite of the disparity the number of female teachers increased in the period from 2012 to 2017 at both types of the universities.

Table 7. Percentage of female teachers in public and private universities of Bangladesh

\begin{tabular}{|c|c|c|c|c|c|c|c|}
\hline Year & \multicolumn{2}{|c|}{ Teachers of Public University } & \multicolumn{2}{|c|}{ Teachers of Private University } & \multicolumn{2}{|c|}{ No of University } & \multirow[t]{2}{*}{ Total No. of Universities } \\
\hline & Total No. of Teachers & Women (\%) & Total No. of Teachers & Women (\%) & Public & Private & \\
\hline 2017 & 13,168 & $\begin{array}{c}3054 \\
(23.19)\end{array}$ & 15,400 & $\begin{array}{c}4378 \\
(28.43)\end{array}$ & 40 & 95 & 135 \\
\hline 2016 & 12,748 & $\begin{array}{c}2887 \\
(22.65)\end{array}$ & 14,986 & $\begin{array}{c}4343 \\
(28.86)\end{array}$ & 38 & 92 & 130 \\
\hline 2015 & 12,414 & $\begin{array}{c}2721 \\
(21.92)\end{array}$ & 13,905 & $\begin{array}{c}3983 \\
(28.64)\end{array}$ & 37 & 85 & 122 \\
\hline 2014 & 11,505 & $\begin{array}{c}2377 \\
(20.66)\end{array}$ & 12,522 & $\begin{array}{c}3684 \\
(29.42)\end{array}$ & 34 & 78 & 112 \\
\hline 2013 & 11,252 & $\begin{array}{c}1308 \\
(11.26)\end{array}$ & 11,882 & $\begin{array}{c}1707 \\
(14.40)\end{array}$ & 34 & 77 & 111 \\
\hline 2012 & 9,962 & $\begin{array}{c}1931 \\
(19.38)\end{array}$ & 10,683 & $\begin{array}{c}2784 \\
(26.06)\end{array}$ & 34 & 52 & 86 \\
\hline
\end{tabular}

Source: BANBEIS-Educational Database

In Table 8, only 36 (17.14\%) teachers were women out of the 210 in DUET whereas 231 (38.50\%) female teachers in Jagannath University that is the highest number of female teachers out of 10 different public universities in Bangladesh in 2017.

Table 8. Percentage of female teachers of public universities of Bangladesh in 2017

\begin{tabular}{|c|c|c|c|c|}
\hline Sl & Name of University & Women Teachers & $\begin{array}{c}\text { Total No. of } \\
\text { Teachers }\end{array}$ & $\begin{array}{c}\text { Percentage of } \\
\text { Women } \\
\text { Teachers (\%) }\end{array}$ \\
\hline 1. & Bangladesh University of Engineering \& Technology (BUET) & 142 & 686 & 20.70 \\
\hline 2. & University of Dhaka (DU) & 676 & 2,257 & 29.95 \\
\hline 3. & Jahangirnagar University (JU) & 206 & 752 & 27.39 \\
\hline 4. & Bangladesh Agricultural University (BAU) & 117 & 593 & 19.73 \\
\hline 5. & University of Rajshahi (RU) & 221 & 1,220 & 18.11 \\
\hline 6. & University of Chittagong (CU) & 225 & 1,179 & 19.08 \\
\hline 7. & Dhaka University of Engineering \& Technology (DUET) & 36 & 210 & 17.14 \\
\hline 8. & Khulna University (KU) & 86 & 402 & 21.39 \\
\hline 9. & Jagannath University & 231 & 600 & 38.50 \\
\hline 10. & Mawlana Bhashani Science \& Technology University (MBSTU) & 32 & 169 & 18.93 \\
\hline
\end{tabular}

\section{Source: UGC Bangladesh 2017}

In Table 9, we found that the percentage of female teachers 17.32 in RU whereas 38.38\% female teachers in Jagannath University and the highest number of female teachers working in Jagannath university that is shown in Table 10.

Table 9. Percentage of female teachers of public universities of Bangladesh in 2016

\begin{tabular}{|c|c|c|c|c|}
\hline SL & Name of University & $\begin{array}{c}\text { Women } \\
\text { Teachers }\end{array}$ & $\begin{array}{c}\text { Total No. of } \\
\text { Teachers }\end{array}$ & $\begin{array}{c}\text { Percentage of Women } \\
\text { Teachers (\%) }\end{array}$ \\
\hline 1. & Bangladesh University of Engineering \& Technology (BUET) & 133 & 660 & 20.15 \\
\hline 2. & University of Dhaka (DU) & 678 & 2,306 & 29.40 \\
\hline 3. & Jahangirnagar University (JU) & 205 & 736 & 27.85 \\
\hline 4. & Bangladesh Agricultural University (BAU) & 118 & 605 & 19.5 \\
\hline 5. & University of Rajshahi (RU) & 213 & 1,230 & 17.32 \\
\hline 6. & University of Chittagong (CU) & 218 & 1,180 & 18.47 \\
\hline 7. & Dhaka University of Engineering \& Technology (DUET) & 36 & 202 & 17.82 \\
\hline 8. & Khulna University (KU) & 77 & 396 & 19.44 \\
\hline 9. & Jagannath University & 213 & 555 & 38.38 \\
\hline 10. & Mawlana Bhashani Science \& Technology University (MBSTU) & 32 & 157 & 20.38 \\
\hline
\end{tabular}


Table 10. Percentage of female teachers of public universities of Bangladesh in 2015

\begin{tabular}{|c|c|c|c|c|}
\hline SL & Name of University & $\begin{array}{c}\text { Women } \\
\text { Teachers }\end{array}$ & $\begin{array}{c}\text { Total No. of } \\
\text { Teachers }\end{array}$ & $\begin{array}{c}\text { Percentage of Women } \\
\text { Teachers (\%) }\end{array}$ \\
\hline 1. & $\begin{array}{c}\text { Bangladesh University of Engineering \& Technology } \\
\text { (BUET }\end{array}$ & 161 & 676 & 23.82 \\
\hline 2. & University of Dhaka (DU) & 622 & 2,156 & 25.85 \\
\hline 3. & Jahangirnagar University (JU) & 192 & 755 & 18.13 \\
\hline 4. & Bangladesh Agricultural University (BAU) & 103 & 568 & 17.29 \\
\hline 5. & University of Rajshahi (RU) & 216 & 1,249 & 17.51 \\
\hline 6. & University of Chittagong (CU) & 197 & 16.18 \\
\hline 7. & Dhaka University of Engineering \& Technology & 28 & 16.41 \\
\hline 8. & Khulna University (KU) & 64 & 390 & 38.24 \\
\hline 9. & Jagannath University & 208 & 544 & 13.47 \\
\hline 10. & Mawlana Bhashani Science \& Technology University \\
\hline
\end{tabular}

Source: UGC Bangladesh 2015

In Table 11, we found that the percentage of female teachers tends to decrease with higher ranks, $31.8 \%$ for lecturers, $25.6 \%$ for assistant professors, $23.1 \%$ for associate professors, and 22.8\% for professors. Despite this trend, the difference is not large, and may reflect the fact that more women are available in the workforce at junior levels.

Table 11. Women Teachers of Dhaka University in Bangladesh

\begin{tabular}{|c|c|c|c|c|c|c|c|c|c|c|}
\hline \multirow[b]{2}{*}{ Schools } & \multicolumn{2}{|c|}{ All Teachers } & \multicolumn{2}{|c|}{ Professor } & \multicolumn{2}{|c|}{ Associate Prof. } & \multicolumn{2}{|c|}{ Assistant Prof. } & \multicolumn{2}{|c|}{ Lecturer } \\
\hline & Total & $\begin{array}{c}\text { Women } \\
(\%)\end{array}$ & Total & $\begin{array}{c}\text { Women } \\
(\%)\end{array}$ & Total & $\begin{array}{c}\text { Women } \\
(\%)\end{array}$ & Total & $\begin{array}{c}\text { Women } \\
(\%)\end{array}$ & Total & $\begin{array}{c}\text { Women } \\
(\%)\end{array}$ \\
\hline Science & 157 & 34 (21.7) & 72 & 19 (26.3) & 26 & $4(15.4)$ & 29 & $4(13.8)$ & 30 & $7(23.3)$ \\
\hline Eng. Sci. & 114 & 18 (15.9) & 34 & $\begin{array}{c}3 \\
(8.8)\end{array}$ & 19 & $\begin{array}{c}3 \\
(15.8)\end{array}$ & 29 & $\begin{array}{c}5 \\
(17.2)\end{array}$ & 32 & $\begin{array}{c}7 \\
(21.9) \\
\end{array}$ \\
\hline Earth Sci. & 53 & 10 (18.9) & 25 & $5(20.0)$ & 11 & $\begin{array}{c}1 \\
(9.1)\end{array}$ & 8 & $\begin{array}{c}3 \\
(37.5)\end{array}$ & 9 & $\begin{array}{c}1 \\
(11.1)\end{array}$ \\
\hline Bio Sci. & 213 & 77 (36.2) & 108 & $\begin{array}{c}29 \\
(26.9)\end{array}$ & 27 & $\begin{array}{c}12 \\
(44.4)\end{array}$ & 38 & $\begin{array}{c}15 \\
(39.5)\end{array}$ & 40 & $\begin{array}{c}21 \\
(52.5)\end{array}$ \\
\hline Pharmacy & 75 & $16(21.3)$ & 29 & $\begin{array}{c}5 \\
(17.2) \\
\end{array}$ & 8 & $\begin{array}{c}1 \\
(12.5)\end{array}$ & 17 & $\begin{array}{c}4 \\
(23.5)\end{array}$ & 21 & $\begin{array}{c}6 \\
(28.6) \\
\end{array}$ \\
\hline Total & 612 & 155 (25.3) & 268 & $\begin{array}{c}61 \\
(22.8)\end{array}$ & 91 & $\begin{array}{c}21 \\
(23.1)\end{array}$ & 121 & $\begin{array}{c}31 \\
(25.6)\end{array}$ & 132 & $\begin{array}{c}42 \\
(31.8)\end{array}$ \\
\hline
\end{tabular}

Source: Dhaka University 2014

As shown in Table 12, the percentage of women professors in BUET and BAU are still low, there are increasing trends during the past 10 years in both the universities.

Table 12. Percentage of female professors in two universities in Bangladesh

\begin{tabular}{|c|c|c|c|c|}
\hline \multirow{2}{*}{ Year } & \multicolumn{2}{|c|}{ BUET } & \multicolumn{2}{c|}{ BAU } \\
\cline { 2 - 5 } & Total No. of Professors & Women (\%) & Total No. of Professors & Women (\%) \\
\hline 2002 & 479 & $65(13.6)$ & 438 & $30(8.2)$ \\
\hline 2004 & 507 & $67(13.2)$ & 474 & $44(8.5)$ \\
\hline 2006 & 519 & $77(14.8)$ & 493 & $52(9.5)$ \\
\hline 2009 & 578 & $100(17.3)$ & 471 & $57(10.8)$ \\
\hline 2010 & 649 & $128(19.7)$ & 464 & $59(11.3)$ \\
\hline
\end{tabular}

Source: BBS 2010

For a typical R/D organization like Bangladesh Atomic Energy Commission (BAEC), there are many more women in the junior positions and the percentage of females' decreases with higher rank. Table 13 gives the data of women scientists in BAEC. 
Table 13. Women Scientists of BAEC

\begin{tabular}{|c|c|c|}
\hline Category & Total No. of Scientists & Percentage of Women Scientists (\%) \\
\hline Chief Scientific officer & 49 & $12(24.4)$ \\
\hline Principal Scientific officer & 91 & $27(29.6)$ \\
\hline Senior Scientific officer & 131 & $39(29.7)$ \\
\hline Scientific officer & 69 & $46(66.6)$ \\
\hline
\end{tabular}

Source: BAEC 2014

Table 14. Women Teachers of BRAC University in following Subjects

\begin{tabular}{|c|c|c|c|c|c|c|c|c|c|c|}
\hline \multirow[b]{2}{*}{ Department } & \multicolumn{2}{|c|}{ Professors } & \multicolumn{2}{|c|}{ Associate Prof. } & \multicolumn{2}{|c|}{ Assistant Prof. } & \multicolumn{2}{|c|}{ Lecturer } & \multicolumn{2}{|c|}{ All Teachers } \\
\hline & Total & $\begin{array}{c}\text { Women } \\
(\%)\end{array}$ & Total & $\begin{array}{c}\text { Women } \\
(\%)\end{array}$ & Total & Women (\%) & Total & $\begin{array}{c}\text { Women } \\
(\%)\end{array}$ & Total & $\begin{array}{c}\text { Women } \\
(\%)\end{array}$ \\
\hline CSE & 2 & 0 & 5 & 0 & 7 & $\begin{array}{c}1 \\
(14.28)\end{array}$ & 45 & $\begin{array}{c}15 \\
(33.33)\end{array}$ & 59 & $\begin{array}{c}16 \\
(27.12)\end{array}$ \\
\hline EEE & 3 & 0 & 1 & 0 & 1 & $\begin{array}{c}0 \\
(50)\end{array}$ & 12 & $\begin{array}{c}6 \\
(43.75)\end{array}$ & 17 & $\begin{array}{c}6 \\
(35.29) \\
\end{array}$ \\
\hline Architecture & 1 & $\begin{array}{c}1 \\
(66.67) \\
\end{array}$ & 4 & 1 & 2 & $\begin{array}{c}1 \\
(37.5)\end{array}$ & 12 & $\begin{array}{c}4 \\
(30) \\
\end{array}$ & 19 & $\begin{array}{c}7 \\
(36.84) \\
\end{array}$ \\
\hline MNS & 4 & 1 & 3 & 2 & 12 & $\begin{array}{c}2 \\
(50)\end{array}$ & 32 & $\begin{array}{c}16 \\
(35.71)\end{array}$ & 51 & $\begin{array}{c}21 \\
(41.18) \\
\end{array}$ \\
\hline Pharmacy & 1 & $\begin{array}{c}1 \\
(100)\end{array}$ & 5 & $\begin{array}{c}2 \\
(40)\end{array}$ & 3 & $\begin{array}{c}1 \\
(33.33)\end{array}$ & 20 & $\begin{array}{c}7 \\
(35)\end{array}$ & 29 & $\begin{array}{c}11 \\
(37.93)\end{array}$ \\
\hline Total & 11 & $\begin{array}{c}3 \\
(27.27) \\
\end{array}$ & 18 & $\begin{array}{c}5 \\
(27.78)\end{array}$ & 25 & $\begin{array}{c}5 \\
(20) \\
\end{array}$ & 121 & $\begin{array}{c}48 \\
(39.67)\end{array}$ & 175 & $\begin{array}{c}61 \\
(34.86) \\
\end{array}$ \\
\hline
\end{tabular}

Source: www.bracu.ac.bd

In a typical private university like BRAC university Table 14 shows that the percentage of female teachers tend to decrease with higher rank $39.67 \%$ for Lecturers, $20 \%$ for Assistant Professors, 27.78\% for Associate Professors and 27.27\% for Professors. We see that more female are available in the workforce at junior levels.

\section{Results}

There is a strong underrepresentation of women in higher positions of academic and scientific institutions in Bangladesh. The advancement of women in many sectors is quite satisfactory but enhancement of women's participation in science and technology is still far from satisfactory. The gender distribution in teaching staff and the student's enrolment shows an alarming gender disparity. Number of female students in both the public and private universities is less than $30 \%$ of the male counterpart. In Table 11, the percentage of women teachers - as Professors in bio-sciences is the highest $(26.9 \%)$ and lowest in engineering (8.8\%), while in case of lecturers women represent $52.55 \%$ in bio-sciences and $21.9 \%$ in engineering science of Dhaka University, one of the topmost universities of the country. In BUET the percentage of female teacher has been gradually increasing since 2002 (BBS, 2010 and UGC Annual Report 2010), rising from $13.6 \%$ in 2002 to $19.7 \%$ in 2010 (see Table 12). It is obvious from all the data presented in these tables that the percentage of female teachers is significantly less than that of male teachers. Total number of scientists in BAEC is 460 of which 124 were women scientists. The percentage of women scientists at the top of the ladder in BAEC i.e. Chief Scientific officer is $24.4 \%$ and in the starting category scientific officer is 66.6 as shown in Table 13. In recent years Government of the People's Republic of Bangladesh has formulated some policies to reduce the discrimination against women in general science and technology. The National Science and Technology Policy 2011 has given special emphasis on participation of women in science and technology, promoting higher education for women at home and abroad ensuring their proper recognition in different scientific organizations. The Ministry of Women and Children Affairs has formulated National Women's Development Policy 2011 and has identified serious gap of women's place in professional life. The present government has set the vision of building a "Digital Bangladesh" by 2021. "Digital Bangladesh" aims at an e-state combining with e-governance, e-banking and e-commerce, e-learning, e-agriculture, e-health, and so on. The vision encompasses much more and takes into account a strong correlation between economic and social development of a country and its achievement in science and technology. Women's participation in this sector has been given special importance. A knowledge based society, efficient management and skilled human resources for both males and females as well calls for extending ICT facility to every nook and corner of the country. In Bangladesh women's involvement in ICT industries and ICT based government and non-government organizations has increased and has changed the behavioral aspect of girls' and women's lifestyle resulting in confidence building in 
the female community.

\section{Conclusions}

Science and Technology assists as the engine of enlargement of a country and an engine of revolution for the people. The human life is rationalized for the progress in this field. There is a straight association between development of a country and its practice of science and technology. Bangladesh is a developing country and half of the total population is women. Here men and women do not contribute similarly in social improvement since the society of gender discrepancy that is difficult for women to stay parallel and enjoy the right of equal contributor. To recover the situation, certain reasonable steps are desired to be undertaken not only by the governments but also by the teachers and managements. Women are committed to improve themselves as leaders through education, networking, and information sharing. In recent years Government of the People's Republic of Bangladesh has articulated certain strategies to reduce the discrimination against women in general science and technology. The findings of this study indicate that the percentage of female students, teachers and scientists are deliberately increased in STEM field.

\section{REFERENCES}

[1] Nath, S. R., Sylva, K., \& Grimes, J. (1999). Raising basic education levels in rural Bangladesh: the impact of a non-formal education programme. International Review of education, 45(1), 5-26.

[2] Helvaci, S. C., \& Helvaci, İ. (2019). An Interdisciplinary Environmental Education Approach: Determining the Effects of E-STEM Activity on Environmental Awareness. Universal Journal of Educational Research, 7(2), 337-346.

[3] Yavuz, M., \& Gülmez, D. (2016). The assessment of service quality perception in higher education. Egitim ve Bilim, 41(184).

[4] Jelena, L. (2010). Determinants of service quality in higher education. Interdisciplinary Management Research, 6, 631-647.

[5] Alam, M., Haque, M. S., \& Siddique, S. F. (2007). Private higher education in Bangladesh. Paris, France: International Institute for Educational Planning.

[6] Baysal, Z. N., \& Araç, K. E. (2019). Conditions Determining Quality in Higher Education: Factors Affecting Satisfaction Levels of Prospective Teachers. Universal Journal of Educational Research, 7(1), 250-258.

[7] Al-Samarrai, S. (2007). Financing basic education in Bangladesh.

[8] Hossain, N. (2004). Access to education for the poor and girls: educational achievements in Bangladesh. In Estudio de caso preparado para la Conferencia Mundial sobre la Reducción de la Pobreza en Gran Escala: A Global Learning Process y conferencia sobre el tema) Shanghai (Vol. 25).

[9] Hahn, Y., Islam, A., Nuzhat, K., Smyth, R., \& Yang, H. S. (2018). Education, marriage, and fertility: Long-term evidence from a female stipend program in Bangladesh. Economic Development and Cultural Change, 66(2), 383-415.

[10] Asadullah, M. N. (2009). Returns to private and public education in Bangladesh and Pakistan: A comparative analysis. Journal of Asian economics, 20(1), 77-86.

[11] Parveen, S. (2007). Gender awareness of rural women in Bangladesh. Journal of International Women's Studies, 9(1), 253-269.

[12] Alam, G. M. (2009). The role of science and technology education at network age population for sustainable development of Bangladesh through human resource advancement. Scientific Research and Essays, 4(11), 1260-1270. 